\title{
Cheah Boon Kheng
}

FROM PKI TO THE COMINTERN, 1924-1941:

THE APPRENTICESHIP OF THE MALAYAN COMMUNIST PARTY

\author{
Selected Documents and Discusssion \\ COMPILED AND EDITED WITH INTRODUCTIONS
}

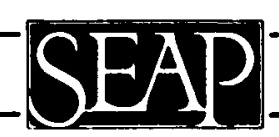

Southeast Asia Program 120 Uris Hall

Cornell University, Ithaca, New York 1992 
(C) 1992 Cornell Southeast Asia Program

ISBN 0-87727-125-9

\section{About the Author}

Cheah Boon Kheng, who received his BA and MA from the University of Malaya and his PhD in Southeast Asian History from Australian National University in 1979, is currently Professor of History in the School of Humanities, at Universiti Sains Malaysia in Penang. 